BLS 33, No 1 2007. DOI: http://dx.doi.org/10.3765/bls.v33i1.3536

(published by the Berkeley Linguistics Society and the Linguistic Society of America)

\title{
Phrasal Tone Domains in San Mateo Huave ${ }^{1}$
}

\author{
MARJORIE PAK \\ University of Pennsylvania
}

\section{Introduction}

The dialect of Huave (isolate) spoken in San Mateo del Mar, Mexico, has a rule of $\mathrm{H}$ Tone Spread (HTS) that applies across words in certain syntactic contexts. HTS is demonstrated in (1)-(2), with phonological domains marked by parentheses. ${ }^{2}$

\section{H L L L H}

(xíkè) (tà-n-àxóm tíil tííd nóp kóchíl )

1s.pro pst-sub-find in street one knife

'I found a knife in the street.'

$$
\begin{aligned}
& \text { L HL L } \\
& \text { (òxêp) (àp-m-f́ch ákókiáw chípín áágá náxéy kiáh mí-kwál xé-kómbíl) } \\
& \text { tomorrow fut-sub-give five tomato the man that poss-son 1poss-friend } \\
& \text { 'Tomorrow my friend's son will give five tomatoes to that man.' }
\end{aligned}
$$

The first word in both of these utterances - a subject in (1) and an adverb in (2) forms a phonological domain of its own, with a (L)HL melody and no rightward spreading of $\mathrm{H}$. The remaining words in each utterance - including the postverbal locative PP in (1) and the postverbal subject in (2) - are all grouped together into a single tone domain, with $\mathrm{H}$ docking on the heavy final syllable of the verb and spreading rightward to the end of the sentence.

Taken together with other data reported here $(\S 2)$, these examples show that: (i) Huave tone domains are potentially quite large, in terms of both phonological weight and syntactic complexity; but (ii) HTS does not apply 'across the board,' since preverbal subjects and time/place adverbs consistently phrase separately.

\footnotetext{
1 Many thanks to Gene Buckley, Aviad Eilam, David Embick, Keelan Evanini, Larry Hyman, Rolf Noyer, Joel Wallenberg, and our generous hosts and informants in San Mateo del Mar.

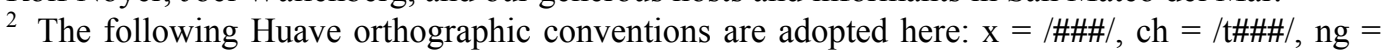
$/ \mathrm{yg} /, \mathrm{y}=/ \mathrm{j} /$. In syllables containing palatal glides (usually transcribed with e or i), tone is marked only on the nuclear vowel.
} 


\section{Marjorie Pak}

The goal of this paper is to provide a fuller description and formal analysis of this pattern. An important question addressed here is why the phonology should treat preverbal subjects and adverbs as special, without also distinguishing their postverbal counterparts. I propose that preverbal subjects and adverbs are in fact structurally higher than postverbal subjects and adverbs - in a clause-peripheral 'topic' or 'edge' position - and therefore are spelled out separately from the rest of the clause (\$3). In the cyclic-spellout or phase-based architecture underlying this proposal, the phonology deals directly with individual substructures (or phases) as they are spelled out, and is thus predicted to 'respect' the underlying syntactic constituent structure in a way that is transparent and regular in the default case. This type of model places tight restrictions on the possible range of syntax-phonology interactions, the implication being that the phonology can provide a reliable source of information about the syntax once we understand how to interpret it. I will contrast this approach with one that allows the phonology to access an arbitrary range of information about linear order, category labels, etc. in addition to constituent structure, and will show that this latter approach makes incorrect predictions both cross-linguistically and in the case at hand. In particular, we will see that the notions of clause and clause edge play a predictable role in Huave phonology across a range of structures, and that the fullvs. reduced-clause distinction plays a corresponding role in the syntax (§4).

\section{Background on Huave Morphosyntax and Tone}

Huave is a pro-drop language. Verbs are inflected for person number subject agreement, tense, and what can roughly be called 'subordination' (labeled 'sub' in glosses here). Inflection on nouns is minimal - case, for example, is not distinguished except by possessive affixes and an optional final vowel on subject pronouns (Stairs and Hollenbach 1981).

While some aspects of word order are fixed - e.g. possessees always precede possessors - the position of other elements in the sentence appears to vary depending on argument structure, discourse status, and other factors. The 'default' position of the subject (when overt) is particularly unclear: Huave has been variously described as SVO (Campbell et al. 1986:547; SIL Ethnologue), VOS (Fromkin and Rodman 1998:470), and VS/SVO (with the position of the subject influenced by the transitivity of the verb (Stairs and Hollenbach 1981:335)).

In our elicitations speakers generally accepted SV, VS, SVO and VOS sentences as grammatical in out-of-the-blue contexts. VSO order, on the other hand, does not seem to occur unless (a) the object is a clause $\left(\mathrm{O}_{\mathrm{CL}}\right)$, and $(\mathrm{b})$ the subject is postverbal - in which case $\mathrm{VSO}_{\mathrm{CL}}$ order appears to be obligatory:

a. ngom m-ahaw [naxey kam $]_{\mathrm{SBJ}}[\text { tiil mi-ntah akiïb }]_{\mathrm{CL}}$ not sub-see man this if poss-wife accompany

'This man didn't know if his wife was with him.' (Radin 1929:4)

b. * ngom mahaw tiil mintah akiiłb [naxey kam $]_{\mathrm{SBJ}}$ 
I assume that $\mathrm{VSO}_{\mathrm{CL}}$ order is derived by obligatory extraposition of complement clauses to a position past the postverbal subject. Whether clausal extraposition is general or restricted to sentences with postverbal subjects is not yet clear.

With respect to tone, the basic generalization for San Mateo Huave is that there is exactly one pitch peak per tone domain, so any time we see a fall from $\mathrm{H}$ to L (e.g. at the end of the subject xike in (1)) we know that a domain boundary has been reached. However, the exact shape of the basic phrasal $\left(\mathrm{L}_{n}\right) \mathrm{H}_{n}(\mathrm{~L})$ melody varies considerably from phrase to phrase: the $\mathrm{H}$ pitch peak may be realized on a single syllable, as part of a HL contour tone, or spread over several syllables, and may or may not be preceded by a series of $\mathrm{L}$ tones. Furthermore, tonal contrast on words in isolation are often neutralized in phrasal contexts:

(4) Tonal contrast between final $\mathrm{H}$ and final $\mathrm{HL}$ on words in isolation:

a. Final H: kàwák 'fruit tree', chíl 'fish', nàdám 'big', sàmpíy 'coyote'

b. Final HL: kàwâk'south', chîl 'needle', nàngân 'sweet', kôy 'rabbit'

(5) Neutralization of word-level tone contrasts in phrasal contexts:
a. (t-àhàw-ás nádám sámpíy tí-lám) (< sàmpíy) pst-see-1/pst big coyote in-river 'I saw a big coyote in the river.'
b. (t-àhàw-ás nádám kóy tí-lám) (< kôy) pst-see-1/pst big rabbit in-river 'I saw a big rabbit in the river.'

To explain these facts, Noyer (1991) argues that tones are assigned at the level of the phrase in San Mateo Huave. More specifically, words are grouped into phrases (or tone domains) in a way that will be discussed in detail in $\S \S 2-3$, and tones are assigned to each phrase by the following algorithm:

1. Some words (e.g. (4)b) have a floating Lexical $L$, which is licensed (linked) only at the right edge of a phrase ((6)a).

2. A Phrasal $H$ tone docks on the primary-stressed (final if heavy, else penultimate) syllable of the 'head' of the phrase. If this syllable already has Lexical L, then a HL contour tone is produced ((6)b).

3. H Tone Spread (HTS): Phrasal H spreads rightward to the end of the phrase, stopping at the penult iff the final syllable already has Lexical L $((6) \mathrm{c})$.

4. Remaining syllables receive Default $L((6) \mathrm{d})$.

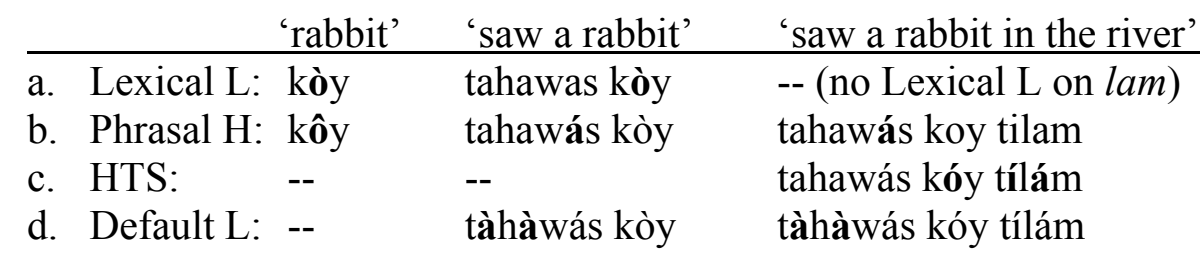




\section{Marjorie Pak}

Noyer's analysis successfully accounts for the distribution of tones within phrases and will be adopted here without modification (see Evanini, this volume, for discussion of how these rules relate to surface pitch and duration). The remainder of this paper focuses on how phrasal tone domains are derived in the first place.

\section{The Current Study: Tone and Syntax in San Mateo Huave}

Noyer's primary data source, Pike and Warkentin 1961, provides a number of descriptive generalizations leading to the claim that 'tone is used extensively for syntactic purposes' in San Mateo Huave (627). The basic pattern reported there is:

(7) A verb is grouped together with a following object and/or adverb into a single tone domain, while preverbal subjects form their own tone domains.

This pattern is confirmed by the current study, which draws on a new corpus of 334 recorded phrases elicited from five native speakers (4F, 1M, ages 14-45) during on-site linguistic interviews in 2004 and $2006 .{ }^{3}$ This pattern was also found to extend to ditransitive verbs, which are not addressed in Pike and Warkentin 1961 - i.e., the verb groups together with all following arguments and modifiers, resulting in a sustained $\mathrm{H}$ plateau of apparently indefinite length, while the subject remains separate regardless of its semantic or prosodic weight:

$$
\begin{aligned}
& \text { (nèhîw) (t-àhch-f́w nérráár yów námbeór íchweàik) } \\
& 3 \text { pro pst-give-3p hot water black monkey } \\
& \text { 'They give hot water to the black monkey.' }
\end{aligned}
$$

Based on the observations in (7) alone, Huave syntax-phonology interactions appear to be fairly straightforward: subjects are usually assumed to be structurally more distant from the verb than objects and it is therefore unsurprising that the phonology should treat them as such. The intuition behind this type of reasoning is that syntactic closeness corresponds to phonological closeness in a very general sense; i.e., there is something about the nature of the syntax-phonology interface that makes phonological rules more likely to apply across weak syntactic junctures than across strong syntactic junctures.

As noted in the introduction, however, things become more complicated when we consider sentences with postverbal subjects - another case that Pike and Warkentin do not address. We found that postverbal subjects consistently group together with the verb, unlike their preverbal counterparts.

\footnotetext{
${ }^{3}$ All five speakers are native to San Mateo and bilingual in Spanish and Huave. Most material was elicited by presenting a phrase in Spanish and asking for the Huave equivalent. In some cases, some or all of the expected Huave words were provided with an English-style 'questioned-list' intonation and the informant was asked to (a) judge whether the resulting sentence was wellformed and (b) say it out loud if it was. Speakers were usually asked to repeat each phrase once. In the handful of cases where the tone phrasing changed from one rendition to another, the two tokens were counted separately; otherwise, each phrase in the corpus is a distinct type.
} 
a. (nèhîw) (t-àhàw-f́w nákánts ólám) they pst-see.3p red cane 'They saw red sugarcane.'

b. (tàhàwíw nákánts ólám néhìw) 'They saw red sugarcane.'
a. (pét) (àntsôr)
dog bark
b. (àntsòr-t́w á pèt)
bark-3p the dog

\author{
'The dog is barking.' \\ 'The dogs are barking.'
}

a. (nìngł́y) (òlám) (ngò m-àtâng)

here cane not sub-grow 'Sugarcane doesn't grow here.'

b. (nìnǵ́y) (ngò màtáng ólám) 'Sugarcane doesn’t grow here.'

This same asymmetry is seen with adverbs of time and place: when such adverbs precede the verb they form their own tone domains; otherwise they group together with the verb and other postverbal arguments and modifiers:
a. (mí-kwál xé-kómb́́l) (àp-m-fích óxép ákókiáw chípín áágá náxéy kiáh) poss-son 1poss-friend fut-sub-give tomorrow five tomato the man that 'My friend's son will give five tomatoes to that man tomorrow.'

b. (òxêp) (àp-m-fích ákókiáw chípín áágá náxéy kiáh mí-kwál xé-kómbúl) tomorrow fut-sub-give five tomato the man that poss-son 1poss-friend 'Tomorrow my friend's son will give five tomatoes to that man.'

Our task, then, is to explain the following asymmetry:

(13) Preverbal subjects and time/place adverbs form their own tone domains, while postverbal subjects and adverbs phrase together with the verb. ${ }^{4}$

\section{Analysis}

The current study has shown that the syntax-phonology relations in Huave are not as straightforward as they may have appeared in earlier work (Pike and Warkentin 1961, Noyer 1991). While preverbal subjects are indeed set apart phonologically from the predicate, a fact that is unsurprising in itself, it is now apparent that postverbal subjects are not set apart but instead group together with the verb.

There are at least two approaches we can pursue at this point: we can abandon the idea that the phonology is constrained primarily by constituent structure and concede that the grammar allows other factors (e.g. linear order, node labels) to take precedence on a case-by-case basis; or we can maintain the idea that phonological closeness corresponds to syntactic closeness and try to find a

\footnotetext{
${ }^{4}$ Preverbal subjects and adverbs phrased separately from the verb in 213 out of 215 relevant unambiguous examples from our elicitation corpus; postverbal subjects and adverbs grouped together with the verb in 54 out of 59 cases. See $\$ 3$ for comments on possible domain variability.
} 


\section{Marjorie Pak}

syntactic explanation for the asymmetry seen here. An example of how the first type of approach might be formalized is given in (14):

(14) Huave syntax-phonology mapping algorithm (to be rejected):

a. The fully linearized syntactic structure is scanned from left to right. Each XP preceding the main verb forms its own tone domain.

b. Once the main verb is reached, scanning ends. A final tone domain begins with the main verb and extends blindly to the end of the utterance, regardless of its internal structure.

Under (14), what matters is the linear order of each XP constituent with respect to the main verb; the prediction is that syntactic structure is irrelevant once the main verb has been reached. In $\S \S 4-5$ we will see that this prediction - in addition to presenting serious complications for any theory of the syntax-phonology interface - is simply incorrect for the case at hand. Huave tone domains do in fact continue to 'see' structure past the first verb; in particular, in sentences containing multiple clauses, each clause forms a separate tone domain. This effect is accounted for automatically in the current model, which I present now.

As mentioned above, I assume a cyclic spellout or phase-based architecture of the grammar, in which syntactic structures are built up and spelled out in stages (or phases). Within this model, spellout occurs at predetermined points (e.g. CP and vP in Chomsky 1999 et seq.). Material within this cut-off point is spelled out together, and material external to it is spelled out on the next cycle. In addition, I assume that phonological rules apply as and/or after each phase is spelled outi.e., spelled-out phases are the basic objects that the phonology deals with.

The question that arises now is how the phase is defined in Huave - and why postverbal subjects are spelled out together with the verb while preverbal subjects are spelled out separately. The hypothesis I pursue here is that postverbal subjects (and adverbs) are structurally closer to the verb than their preverbal counterparts, which occupy a clause-peripheral 'edge' position. More specifically:

Proposal

a. Preverbal subjects and time/place adverbs in Huave obligatorily occupy Spec,CP (a 'topic' position). ${ }^{5}$

b. Postverbal subjects are in a lower position, e.g. Spec,TP or Spec,vP. ${ }^{6}$

c. Spellout is triggered at each CP. Everything within the CP is spelled out together except the material in its 'edge' (i.e. C and Spec,CP), which is spelled out in a separate cycle.

d. Tones are assigned to the spelled-out, linearized output of each phase.

${ }^{5}$ Sentences with multiple preverbal topics (e.g. (11)a) are assumed to have recursive CPs.

${ }^{6}$ There are a number of ways to derive VOS order, including: (i) right-adjunction or rightlinearization of Spec,TP (cf. Aissen 1992, Rizzi 1982); (ii) fronting of the predicate to a position above the subject (cf. Massam 2005), or (iii) serial movement of verb and arguments out of vP (cf. Ordóñez 1998). The question of which analysis is most suitable for Huave is left for future work. 
To illustrate: in the SVO sentence in (16)a, repeated from (9)a, the preverbal subject nehiw is in Spec, $\mathrm{CP}^{7}-$ i.e. at the phase edge - and is therefore excluded from the (boldfaced) CP spellout domain. In the VOS sentence in (16)b, the subject is lower than Spec,CP, e.g. in Spec, $\mathrm{vP}$ or Spec,TP. The CP phase edge is empty, and all of the boldfaced material below $\mathrm{C}$ is spelled out together.

\section{a. SVO: ${ }_{\mathrm{CP}}\left[\right.$ nèhîw ${ }_{\mathrm{TP}}[$ tàhàwíw nákánts ólám $\left.]\right]$ 3p.pro see.pst.3p red cane 'They saw red sugarcane.' \\ b. VOS: ${ }_{\mathrm{CP}}\left[\operatorname{TP}_{\mathrm{T}}[\right.$ tàhàwíw nákánts ólám néhìw $\left.]\right]$}

'They saw red sugarcane.'

While this analysis is intended to derive the syntax-phonology mappings we find in the default case, the model assumed here is also able to accommodate a certain amount of performance-related variability. In Pak (2006) I argue that rules like Huave HTS - which apply to fully linearized, potentially $n$-ary chains of words - apply relatively late in the derivation, when information about speech rate has become available. Such rules are predicted to be variable in a specific way: phases can be broken apart in slow speech or merged in fast speech.

Influence from rate, rhythm, carefulness, and other nonsyntactic factors could very well account for some of the exceptional cases seen in our corpus, although experimental studies and corpus studies of spontaneous speech are needed in order to determine the exact factors involved in Huave tone-domain variability. In the meantime it is worth noting that while our corpus contains several pairs like (17)a-(17)b, where a verb phrase is realized as either one or two tone domains, parses like (17)c are so far unattested.
a. (xíkè) (s-àngàneów cháw pópóx xówíy lángàn) 1s.pro 1-drink atole foam very sweet 'I drink very sweet foam atole (a warm drink).'
b. (xíkè) (sàngàneów cháw pópóx) (xòwł̀y làngân)
c. * (xíké sángáneôw) (chàw pòpóx xówíy lángàn)
(S) (VOAdj)
(S) (VO) (Adj)
* (SV) (OAdj)

In other words, it does not appear to be possible for only a subpart of one phase (the verb (17)c) to 'escape' its tone domain and join another. Accordingly, the analysis I have laid out accommodates cases like (17)b but not cases like (17)c.

\section{Further Support: Reduced and Full Clauses, Extraposition, and Tone}

Within the current proposal, the Huave tone domain is basically a clause minus its edge. Presumably, this treatment could be extended to other languages that have been shown to set apart preverbal subjects phonologically, e.g. tone-association

\footnotetext{
${ }^{7}$ I assume that this subject has either moved from a lower vP-internal position or is coindexed with a pro subject in $\mathrm{vP}$; at this point nothing hinges on the choice between these two options.
} 


\section{Marjorie Pak}

rules in Slave (Rice 1987), Kinande (Hyman 1990), and Luganda (Hyman 1982 et seq., Pak 2007). While the status of preverbal subjects as high, phase-edge elements remains to be established across these languages, ${ }^{8}$ there is independent evidence that the proposal in (15) is on the right track for Huave. I present this evidence next.

So far, all the examples we have seen have been single clauses containing a single verb. According to the proposal in (15), however, spellout is assumed to occur at every $\mathrm{CP}$ node. The proposal therefore makes a clear prediction:

Prediction: In utterances containing more than one clause, each clause should form a separate tone domain.

Based on the data available so far, ${ }^{9}$ this prediction is borne out: finite complement clauses (19), finite adjuncts (20)-(21), relative clauses (21), nonfinite purpose clauses (22), and nonfinite 'want' complements (23) form their own tone domains, separate from the matrix verb:

(nìpilán) (àpì̀ng-t̂w) (àp-m-àndeòw-áàts)

people say-3p fut-sub-die-1p/inc

'People say we will die.' (Pike and Warkentin 1961:639)

(sà-n-àyàk-án ndòk) (kós) (lè-m-àsáh xík)

1 fut-1sub-put-1p/ex net because 2rec.pst-sub-say 1s.pro

'We'll cast our nets because you told me (to).'

(21) (wìx teàt Sìmòn Pédrò) (t-àháw) (leàw t-àráng teát Jésús) (t-àsâh)

when lord Simon Peter pst-see rel pst-do lord Jesus pst-say

'When Simon Peter saw what Jesus had done, he said...'

(s-àhàl-án teát bì̀mb)(pàrà n-àtsánts á yòw)

1-light-1p sir fire for 1sub-reheat det water

'We make a fire to reheat the water.'

(s-àndíìm)(n-àndeák ómbeáy-ìts) (pòrkè m-àhneâh)

1-want 1sub-speak language-1p/inc because sub-beautiful

'I want to speak Huave because it's beautiful.'

\footnotetext{
${ }^{8}$ For example, we might expect to find 'scope freezing' effects - obligatory wide quantifier scope on preverbal subjects - the idea being that the preverbal position is too high to be included in the domain for reconstruction (cf. Alexiadou and Anagnostopoulou 1998 on Greek and Romance).

${ }^{9}$ Viz. our elicitation corpus, Pike and Warkentin 1961, a recording of John 1:1-18 (Liga Bíblica México) and selections from a movie version of St. Luke's gospel (www.jesusfilm.org). Written sources considered in $\S 4$ include example sentences in Stairs and Stairs 1981 and Stairs and Hollenbach 1981; the first ten texts in Radin 1929 (oral narratives in San Dionisio Huave); and a Huave translation of St. John's gospel (Liga Bíblica México 2005).
} 
As predicted by (18), each clause forms its own tone domain in Huave. In (20) the subordinate clause is in turn broken up into separate tone domains; I assume that this is because kos 'because' is in a high edge position while the other connectors seen here (e.g. leaw 'that which,' porke 'because') are located lower in the clause.

A handful of apparent exceptions to this clause-to-domain correspondence have been found, all involving causative constructions with the light verb $\ddot{z} c h$ 'give.' In (24) and (25), ̈̈̈ch groups together with the following subordinateprefixed verb into a single tonal domain, instead of forming its own tone domain like the matrix verbs in (19)-(23). Example (26), from our elicitation corpus, shows intraspeaker variation: $\ddot{*}$ ch grouped together with the following verb on one rendition and phrased separately on another. Notice that all three of these examples are semantically ambiguous as well:

(24) (íké) (ì̀ch m-ámb tíil éskwél mí-kwál)

2s.pro 2.give sub-go to school poss-son

'You make your son go to school / send your son to school.'

(nêh) (t-íin) (ìch nèh m-ìnn teàt diôs)

3s.pro pst-come give 3s.pro sub-come lord god

'He came; God sends him / makes him come.' (Sp: enviado por Dios)

a. (íkè) (teà-m-áàch) (m-àngàneów nángán yów xé-kwál) 2s.pro prog-sub-give sub-drink sweet water 1poss-son

'You're making my son drink soda / giving my son soda to drink / feeding my son soda.'

b. (íkè) (teàmààch màngàneów nángán yów xékwál)

A likely reason for the apparent 'domain fusion' seen in (24)-(25) and (26)b is that the verbal complement in these sentences is not a full $C P$ but rather a reduced structure, which does not 'count' as a phase and therefore gets spelled out together with the matrix verb $\ddot{z} c h$. The idea is that $\ddot{t} c h$ is involved in a number of different constructions, appearing with different-sized complements that are likely associated with different interpretations.

If this idea is on the right track, we might expect the full vs. reduced clause distinction to play a role in other, nonphonological phenomena as well. This expectation is also borne out. Recall that clausal complements are obligatorily extraposed in sentences with postverbal subjects, resulting in $\mathrm{VSO}_{\mathrm{CL}}$ order:
a. ngom m-ahaw [naxey kam $]_{\text {SвJ }}[\text { tiil mi-ntah akiïb }]_{\mathrm{O}_{\mathrm{CL}}}$ not sub-see man this if poss-wife accompany 'This man didn't know if his wife was with him.'
b. * ngom mahaw tiil mintah akiïb [naxey kam $]_{\mathrm{SBJ}}$ 


\section{Marjorie Pak}

$\mathrm{VO}_{\mathrm{CL}} \mathrm{S}$ sentences like (27)b, which appear to be ruled out in general, do occur when the matrix verb is $\ddot{\ddot{t} c h}$. In other words, verbal $\ddot{\ddot{t} c h}$ complements can fail to extrapose, just as they can fail to form separate phonological domains.
a. t-iich xik n-iin [xe-teat dios $]_{\mathrm{SBJ}}$
pst-give 1s.pro 1sub-come 1poss-lord god
'My lord God sent me / made me come.'
b. t-iich m-ahneah omeaats mi-chiig neh [a Juan $]_{\mathrm{SBJ}}$
pst-give sub-beautiful heart poss-brother 3s.pro Juan
'Juan calmed his brother down.' (lit. made his brother's heart good)

In sum, the phonological variability seen with $\ddot{t i c h}$ constructions in (24)-(26) has a structural source: the syntax itself is variable, allowing $\ddot{i c h}$ to occur with either a full $\mathrm{CP}$ or a reduced non-CP complement. As we might expect, restructuring plays a role elsewhere in the grammar as well: $\ddot{t i c h}$ complements can fail to extrapose.

\section{Concluding Remarks}

This paper presented results from a new study of phrasal tone domains in San Mateo Huave. The principal finding was that preverbal subjects and adverbs consistently form their own tone domains, separate from the predicate, while postverbal subjects and adverbs phrase together with the preceding verb. The question addressed here was what the source of this pattern is.

The range of possible answers to such questions is of course circumscribed by the model of the syntax-phonology interface assumed. I have adopted a model in which phonological rules apply directly to the syntactic objects that are spelled out at designated stages in the derivation - i.e. a model that predicts a transparent correspondence between the syntax and the phonology in the default case - and consequently I pursued the idea that the phonological asymmetry reported here is the result of an underlying syntactic asymmetry. Specifically, I argued that preverbal subjects and adverbs are structurally higher than their postverbal counterparts, in a clause-peripheral position at the 'edge' of the $\mathrm{CP}$ phase, and thus undergo spellout separately from the verb.

At the beginning of $\S 3$ (see (14)) I briefly considered an alternative account, one that made use of a hybrid mix of linear relations, node labels and constituency relations in order to derive the preverbal/postverbal asymmetry reported here. According to this algorithm the first verb in the string is predicted to group together with everything that follows, regardless of the internal syntactic structure of the resulting domain. This type of treatment is unformulable in the phase-based grammar assumed here, since it simultaneously requires that the entire linearized string be taken into account and requires reference to aspects of the constituent structure (XP status of preverbal constituents, category of the verb). Furthermore, as shown in $\S 4$, this algorithm makes the wrong prediction: the leftmost verb does not blindly group together with everything that follows; instead, clausal complements and adjuncts consistently form their own domains. 


\section{Phrasal Tone Domains in San Mateo Huave}

Of course we could alter (14) to derive the clause-sensitivity effect seen in (19)-(23) - e.g. by restricting the tone domain to 'the next clause boundary' - but such a modification would be basically arbitrary. If we admit such statements we might as well also admit statements limiting tone domains to 'the next noun phrase' or 'the next quantifier' - thus ruling in all kinds of category-sensitivity effects that play no role in attested syntax-phonology mappings. We could, for example, generate an algorithm like (29) as a logical possibility:

a. A phonological break occurs (only) after every adjective in the string.

b. My best / friend drank a small / black / coffee while I read a new / book.

Mappings like (29) are unattested, and as such have been systematically ruled out by models of the syntax-phonology interface going back to word-boundary theory (Chomsky and Halle 1968) and including most versions of XP-edge alignment (Chen 1987, Selkirk 1986). Accordingly, phonological rules that appear at first sight to require reference to an hybrid assortment of arbitrary information, as in (14), require careful examination. In the case of Huave, we found that tone domains are in fact consistently clause-bounded - an automatic result in the architecture assumed here, where clauses are phases - and that variation in this clause-to-domain correspondence is attributable to variation in clause size with certain (restructuring) predicates. In the course of this case study, what started as a phonological observation led to a new insight about the syntax - another consequence of adopting a model in which syntax-phonology interactions are predicted to be transparent and regular in the default case.

\section{References}

Aissen, Judith L. 1992. Topic and Focus in Mayan. Language 68:43-80.

Alexiadou, Artemis and Elena Anagnostopoulou. 1998. Parametrizing Agr: Word Order, Verb-Movement and EPP-Checking. Natural Language and Linguistic Theory 16:491-539.

Campbell, Lyle, Terrence Kaufman, and Thomas C. Smith-Stark. 1986. MesoAmerica as a Linguistic Area. Language 62:530-570.

Chen, Matthew. 1987. The Syntax of Xiamen Tone Sandhi. Phonology Yearbook 4:109-149.

Chomsky, Noam. 1999. Derivation by Phase. MIT Occasional Papers in Linguistics, Vol. 18. Cambridge, MA: MIT.

Chomsky, Noam and Morris Halle. 1968. The Sound Pattern of English. New York: Harper and Row.

Evanini, Keelan. 2007. The Phonetic Realization of Pitch Accent in Huave. Proceedings of BLS 33.

Fromkin, Victoria and Robert Rodman. 1998. An Introduction to Language. New York: Harcourt Brace. 


\section{Marjorie Pak}

Hyman, Larry M. 1982. Globality and the Accentual Analysis of Luganda Tone. Journal of Linguistic Research 2/3:1-40.

Hyman, Larry M. 1990. Boundary Tonology and the Prosodic Hierarchy. In S. Inkelas and D. Zec, eds., The Phonology-Syntax Connection, 109-125. Chicago: University of Chicago Press.

La Liga Bíblica México. 2005. Najneaj nanderac leaw tapiüng San Juan wüx Teat Cristo. Electronic Version.

Massam, Diane. 2005. Lexical Categories, Lack of Inflection, and PredicateFronting in Niuean. In A. Carnie, H. Harley, and S. Dooley, eds., Verb First: On the Syntax of Verb-Initial Languages, 227-242. Amsterdam: Benjamins.

Noyer, Rolf. 1991. Tone and Stress in the San Mateo Dialect of Huave. Proceedings of ESCOL '91, 277-288.

Ordóñez, Francisco. 1998. Postverbal asymmetries in Spanish. Natural Language and Linguistic Theory 16(2):313-346.

Pak, Marjorie. 2006. The Postsyntactic Derivation and Its Phonological Reflexes. Ms., University of Pennsylvania.

Pak, Marjorie. 2007. Clause Size and Tone Domains in Huave and Luganda. Paper presented at SPINE-3, Cornell University.

Pike, Kenneth L. and Milton Warkentin. 1961. Huave: A Study in Syntactic Tone with Low Lexical Functional Load. In B. F. Elson and J. Comas, eds., $A$ William Cameron Townsend en el vigésimoquinto aniversario del Instituto Lingüístico de Verano, 627-42. SIL, Mexico.

Radin, Paul. 1929. Huave Texts. International Journal of American Linguistics 5:1-56.

Rice, Keren. 1987. On Defining the Intonational Phrase: Evidence from Slave. Phonology Yearbook 4:37-59.

Rizzi, Luigi. 1982. Issues in Italian Syntax. Dordrecht: Foris.

Selkirk, Elisabeth. 1986. On Derived Domains in Sentence Phonology. Phonology Yearbook 3:371-405.

Stairs, Emily F. and Elena E. de Hollenbach. 1981. Gramática huave. In Kreger and Stairs 1981.

Stairs Kreger, Glenn Albert and Emily Florence Scharfe de Stairs. 1981. Diccionario huave de San Mateo del Mar. SIL, Mexico.

\footnotetext{
Marjorie Pak

Department of Linguistics

University of Pennsylvania

619 Williams Hall

Philadelphia, PA 19104-6305

mpak@ling.upenn.edu
} 